\title{
Prolactin affects leptin action in the bovine mammary gland via the mammary fat pad
}

\author{
Y Feuermann ${ }^{1,2}$, S J Mabjeesh ${ }^{2}$, L Niv-Spector ${ }^{3}$, D Levin ${ }^{4}$ and A Shamay ${ }^{1}$ \\ ${ }^{1}$ Institute of Animal Science, Agricultural Research Organization, The Volcani Center, PO Box 6, Bet Dagan 50250, Israel \\ Departments of ${ }^{2}$ Animal Science, ${ }^{3}$ Biochemistry, Faculty of Agricultural, Food and Environmental Quality Sciences, The Hebrew University of Jerusalem, \\ PO Box 12, Rehovot 76100, Israel \\ ${ }^{4}$ Department of Obstetrics and Gynecology, Kaplan Medical Center, Rehovot, Affiliated to the Hebrew University School of Medicine, Jerusalem, Israel \\ (Requests for offprints should be addressed to A Shamay; Email: shamay@agri.huji.ac.il)
}

\begin{abstract}
One of the roles of the endocrine system is to synchronize mammary function. Hormones, such as estrogen, progesterone, and prolactin act directly on the mammary gland. Metabolic hormones, such as GH, glucocorticoids, insulin, and leptin are responsible for coordinating the body's response to metabolic homeostasis. Leptin has been shown to be an important factor in regulating the metabolic adaptation of nutrient partitioning during the energy-consuming processes of lactation. In the present study, we show that leptin is secreted from the mammary fat, and is regulated by prolactin. The expression of $\boldsymbol{\alpha}$-casein in a co-culture of epithelial cells
\end{abstract}

and fat explants was enhanced by prolactin compared with that in epithelial cells cultured alone. Leptin antagonist abolished the effect of leptin on $\boldsymbol{\alpha}$-casein expression in mammary gland explants when exogenous leptin was not present in the medium. This finding supports our hypothesis that the antagonist abolishes the action of endogenous leptin secreted by the mammary adipocytes. These results lead us to the hypothesis that prolactin and leptin act in the bovine mammary gland, via mammary fat pad/adipocytes.

Journal of Endocrinology (2006) 191, 407-413

\section{Introduction}

Milk production after calving in the 'industrial' dairy cow is attributable to an increase in both the biosynthetic activity of mammary tissue and the availability of the substrates necessary for synthesizing the components of milk (Accorsi et al. 2005). Both the endocrine and the metabolic systems are involved in lactation regulation. In the initial phase of lactation, the interaction between the endocrine and the metabolic systems will determine the potential milk yield from the udder. Recent evidence suggests that the adipocyte-epithelial interaction is critical for mammary duct growth and morphogenesis (Zangani et al. 1999). Locally produced growth factors are believed to mediate the adipocyte-epithelial interactions and to alter the actions of several steroid and peptide hormones in these tissues (Hovey et al. 1999). Among the different factors controlling the fate of the mammary gland, leptin may be involved in the metabolic changes occurring during lactation (Feuermann et al. 2004). Leptin, a protein hormone secreted predominantly by white adipose tissue (Friedman \& Halaas 1998), is therefore a key factor in regulating the metabolic adaptation of nutrient partitioning during the energyconsuming processes of pregnancy and lactation (Moschos et al. 2002). Leptin is involved in the regulation of reproduction, bone formation, and many other functions (Fruhbeck 2001). Several hormones, such as insulin, glucocorticoids, tumor necrosis factor- $\alpha$, and prolactin regulate leptin expression at the adipose tissue (Fruhbeck 2001). Prolactin, a hormone secreted from the pituitary acidophil cells, plays an important role in the morphological and biochemical differentiation of the epithelial cells during pregnancy, and regulates milk-protein synthesis during lactation (Groner 2002). The basal level of prolactin increases throughout the course of pregnancy, up to tenfold by term, and remains elevated during the postpartum period in humans (Conn \& Melmed 1997) and in cattle (Accorsi et al. 2005). In a previous study, we demonstrated that prolactin can regulate leptin and leptin receptor gene expression in the bovine mammary gland (Feuermann et al. 2004). We demonstrated that prolactin enhanced leptin receptor expression in the mammary gland of lactating cows, but did not affect that in virgin calves. We also showed that leptin alone has no effect on the lactating mammary gland. The objective of the present study was to determine prolactin effect on leptin action in the bovine mammary gland.

\section{Materials and Methods}

\section{Animals}

Mammary tissue was obtained from five Holstein cows in the slaughterhouse, $2-5$ months after the onset of lactation. 
The Israeli Ministry of Agriculture approved all procedures in accordance with Israeli regulations for animal experimentation.

\section{Materials}

M-199, penicillin, streptomycin, and Fungizone (amphotericin B) were obtained from Bet Haemek, Israel. Bovine insulin, cortisol, and ovine prolactin were purchased from Sigma. Bovine recombinant leptin and leptin antagonist were supplied by Prof. A Gertler (Niv-Spector et al. 2005).

\section{Mammary explants culture}

Mammary tissue and mammary fat tissue were obtained from cows in the slaughterhouse and transferred into medium M-199 containing $100 \mathrm{U}$ penicillin, $100 \mu \mathrm{g}$ streptomycin, $0 \cdot 25 \mu \mathrm{g}$ Fungizone, and $1 \mu \mathrm{g} / \mathrm{ml}$ insulin. Explants were prepared as described previously (Shamay et al. 1987). Twenty explants (50-80 $\mathrm{mg}$ total weight) were placed on an impregnated lens paper floating in $5 \mathrm{ml} \mathrm{M}$-199 medium and were cultured at $37{ }^{\circ} \mathrm{C}$ in a medium supplemented with $1 \mu \mathrm{g} / \mathrm{ml}$ insulin, $0.5 \mu \mathrm{g} / \mathrm{ml}$ cortisol, and prolactin at various concentrations (IFP); or in a medium supplemented only with $1 \mu \mathrm{g} / \mathrm{ml}$ insulin and $0.5 \mu \mathrm{g} / \mathrm{ml}$ cortisol (IF). Leptin and leptin antagonist were added according to the experimental protocol. The medium was changed every $24 \mathrm{~h}$, for 5 days.

\section{Fat explant culture}

Fat tissue from the udder hind were obtained from cows in the slaughterhouse and transferred into medium M-199 containing $100 \mathrm{U}$ penicillin, $100 \mu \mathrm{g}$ streptomycin, $0 \cdot 25 \mu \mathrm{g}$ Fungizone, and $1 \mu \mathrm{g} / \mathrm{ml}$ insulin. Explants were prepared as described previously (Shamay et al. 1987). Three to five explants (30-60 mg total weight) floating in $5 \mathrm{ml} \mathrm{M-199}$ medium were cultured at $37^{\circ} \mathrm{C}$ in a medium supplemented with $1 \mu \mathrm{g} / \mathrm{ml}$ insulin, $0.5 \mu \mathrm{g} / \mathrm{ml}$ cortisol, and prolactin at various concentrations. The medium was changed every $24 \mathrm{~h}$, for 5 days.

\section{Fat-epithelial co-culture}

Bovine mammary gland tissue was transferred to the laboratory, cut into small pieces, and placed in a $500 \mathrm{ml}$ Erlenmeyer flask containing M-199 medium supplemented with $1 \mathrm{mg} / \mathrm{ml}$ collagenase, $1 \mathrm{mg} / \mathrm{ml}$ hyaluronidase, and $1 \mu \mathrm{g} / \mathrm{ml}$ bovine insulin (at a ratio of $10 \mathrm{ml}$ medium: $1 \mathrm{~g}$ tissue). The culture was swirled in a gyrating water bath at 100 r.p.m. and $37^{\circ} \mathrm{C}$ for $3-4$ h. During this period, tissue fragments were further dissociated by occasional aspiration through a $10 \mathrm{ml}$ pipette with a large orifice. One hour before termination of the enzymatic digestion, $0 \cdot 04 \%$ DNase was added at $0.5 \mathrm{ml} / 100 \mathrm{ml}$ digest. At the end of incubation, the suspension was passed through a Nitex filter $(200 \mu \mathrm{m})$ and the cells were washed three to five times with M-199. The cells were grown in a $10 \mathrm{~mm}$ plastic dish in DMEM/F-12 (HAM) $1: 1$, supplemented with $10 \%$ fetal calf serum (FCS), $1 \mu \mathrm{g}$ insulin, $10000 \mathrm{U}$ penicillin, $10 \mathrm{mg}$ streptomycin, $0.025 \mathrm{mg}$ Fungizone, and $0.5 \mathrm{mg} \mathrm{L}$-glutamine $/ \mathrm{ml}$ in a humidified atmosphere of $5 \% \mathrm{CO}_{2}, 95 \%$ air at $37{ }^{\circ} \mathrm{C}$. The medium was changed at 48-h intervals until the start of the experiment. The cells were grown to confluency, dispersed with $0.05 \%$ trypsin, and transferred to other plates. Cells were stored at $-70{ }^{\circ} \mathrm{C}$ in $10 \%$ DMSO and $20 \%$ FCS. The cells used in these experiments underwent not more than six transfers. Once the experiment was begun, fat explants were prepared as described in the Explant Culture section and were added to the primary mammary cells' culture dish for $48 \mathrm{~h}$.

\section{Isolation of $\mathrm{RNA}$}

The total RNA was isolated from the mammary tissue by the acid guanidinium thiocyanate phenol-chloroform extraction method (Chomczynski \& Sacchi 1987). Upon isolation, RNA was kept at $-70{ }^{\circ} \mathrm{C}$ until analysis by reverse transcription-PCR (RT-PCR) or real-time PCR (rt-PCR).

\section{Reverse transcription (RT)}

The total RNA $(1 \mu \mathrm{g})$ was reverse-transcribed in a final volume of $20 \mu \mathrm{l}$ containing $50 \mathrm{mM}$ Tris- $\mathrm{HCl}(\mathrm{pH} 8 \cdot 3)$, $75 \mathrm{mM} \mathrm{KCl}, 5 \mathrm{mM} \mathrm{MgCl}, 10 \mathrm{mM}$ dithiothreitol, $0.5 \mathrm{mM}$ deoxy-NTP (dNTP), $0.5 \mu \mathrm{g}$ oligo-dT/hexamer primers (Promega), and $1 \mathrm{U}$ avian myeloblastosis virus reverse transcriptase (Promega). The reaction temperatures were $42{ }^{\circ} \mathrm{C}$ for $1 \mathrm{~h}$ and $95^{\circ} \mathrm{C}$ for $10 \mathrm{~min}$.

\section{PCR}

The RNA samples were reverse-transcribed as described above. The reaction mixture was diluted to a final volume of $50 \mu \mathrm{l}$. To $50 \mu \mathrm{l}$ PCR mixture $(5 \mu \mathrm{l}$ of $10 \times$ PCR buffer, $1 \mu \mathrm{l}$ dNTP, $1 \mu \mathrm{l}$ Taq DNA polymerase, $2 \mu \mathrm{l}$ forward primer, and $2 \mu \mathrm{l}$ reverse primer), $2 \mu \mathrm{l}$ diluted cDNA was added. The primer sequences for Adipo-Q were: sense $5^{\prime}-\mathrm{GAC}$ AAG GCC GTT CTC TTC AC-3', antisense 5'-AGA CTG TCC TGG GAA CAT GG- $3^{\prime}$. The primer sequences for $\boldsymbol{\alpha}$-casein were: sense $5^{\prime}$-TCT GCA CCT TCC TCT GCC TC-3', antisense $5^{\prime}$-AAA GGG ACA GCA CGG ACT GA-3'. The amplification parameters were initial denaturation at $94{ }^{\circ} \mathrm{C}$ for $2 \mathrm{~min}, 35$ cycles of denaturation at $94{ }^{\circ} \mathrm{C}$ for $45 \mathrm{~s}$, annealing at $59{ }^{\circ} \mathrm{C}$ for $45 \mathrm{~s}$, and extension at $72{ }^{\circ} \mathrm{C}$ for $2 \mathrm{~min}$. There was a final extension at $72{ }^{\circ} \mathrm{C}$ for $7 \mathrm{~min}$. To verify that, equal amounts of RNA, cDNA was tested by RT-PCR for the expression of the housekeeping gene 18S. The primer sequences for $18 \mathrm{~S}$ were: sense $5^{\prime}$-CGG CTA CCA CAT CCA AGG AA-3', antisense $5^{\prime}$-GGG CCT CGA AAG AGT CCT GT-3'. PCR products were size-separated by electrophoresis on $1 \%$ agarose gels. The gels were stained with ethidium bromide. 


\section{Real-time PCR (rt-PCR)}

The RNA samples were reverse-transcribed as described. The samples were analyzed by rt-PCR with the ABI Prism 7000 system (Applied Biosystems, Foster City, CA, USA). A $5 \mu \mathrm{l}$ sample of cDNA was amplified for 40 cycles with $3 \mu \mathrm{l}$ of the following primers at a final concentration of $0.5 \mu \mathrm{M}$ : leptin primers (sense 5'-GGA GAA GGT CCC GGA GGT T-3', antisense $5^{\prime}$-GGA CCA GAC ATT GGC GAT CT-3'), $\boldsymbol{\alpha}$-casein primers (sense $5^{\prime}$-TCT GCA CCT TCC TCT GCC TC-3', antisense 5'-AAA GGG ACA GCA CGG ACT GA- $3^{\prime}$ ), and as a normalizing control, bovine ribosomal $18 \mathrm{~S}$ primers (sense $5^{\prime}$-CGG CTA CCA CAT CCA AGG AA-3', antisense $5^{\prime}$-GGG CCT CGA AAG AGT CCT GT-3') were used. The reaction was carried out in a final volume of $50 \mu \mathrm{l}: 16 \mu \mathrm{l}$ SYBR Green (Applied Biosystems), $3 \mu \mathrm{l}$ of $5 \mu \mathrm{M}$ primer $\operatorname{mix}, 3 \mu \mathrm{l}$ of $5 \mu \mathrm{M}$ reverse primer, $5 \mu \mathrm{l}$ template (cDNA), and $23 \mu \mathrm{l}$ deionized water, for 40 cycles of $1 \mathrm{~min}$ of denaturation at $95{ }^{\circ} \mathrm{C}, 2 \mathrm{~min}$ of annealing at $60{ }^{\circ} \mathrm{C}$, and 1 min of extension at $72{ }^{\circ} \mathrm{C}$. The amplified PCR product was analyzed with ABI Prism 7000 software (Applied Biosystems). At the end of the rt-PCR run, a melting curve was determined to verify the presence of a single amplicon.

\section{Analysis of rt-PCR}

rt-PCR analysis was performed by the ${ }^{\Delta \Delta} \mathrm{CT}$ method (Applied Biosystems). CT stands for the threshold cycle, i.e. the PCR cycle in which an increase in reporter fluorescence above a baseline signal can first be detected. The proportional change detected in mRNA is calculated as $2^{-\Delta \Delta C T}$

$$
\begin{aligned}
{ }^{\Delta \Delta} \mathrm{CT}= & \left(\mathrm{CT}_{\text {assayed gene: treated }}-\mathrm{CT}_{18 \text { s: treated }}\right) \\
& -\left(\mathrm{CT}_{\text {assayed gene: control }}-\mathrm{CT}_{18 \text { s: control }}\right),
\end{aligned}
$$

where subscripts refer to the mRNA of the amplified gene and whether the sample was treated or a control.

\section{RIA for leptin}

The samples of medium were collected from the five fat explant experiments. The medium was concentrated and analyzed for leptin using the DSL (Webster TX, USA) porcine leptin IRMA (DSL-82100). All assays were performed as per the manufacturer's instructions.

\section{Statistical analysis}

All statistical analyses were carried out using the JMP 5.0.1 statistical package from SAS (2001). The explant experiments and leptin secretion and expression experiments were compared using one-way ANOVA. The co-culture experiments were compared by Student's $t$-test.

\section{Results}

Effect of prolactin on leptin expression in the mammary gland of lactating cows

Mammary gland explants from a lactating cow were incubated for 2 days in a medium containing four different levels of prolactin $(0 \cdot 01-10 \mu \mathrm{g} / \mathrm{ml})$. As shown in Fig. 1, addition of prolactin to the medium elevated the level of leptin mRNA expression in the mammary gland explants. A level of 2.5 arbitrary units of leptin mRNA expression in the mammary explants was observed at a prolactin concentration of $1 \mu \mathrm{g} / \mathrm{ml}$. At $10 \mu \mathrm{g} / \mathrm{ml}$ prolactin, leptin expression was down-regulated to $1 \cdot 25$ arbitrary units.

\section{Effect of prolactin on leptin secretion in mammary gland fat explants}

Mammary fat explants from a lactating cow were incubated for 2 days in a medium containing four different levels of prolactin $(0 \cdot 01-10 \mu \mathrm{g} / \mathrm{ml})$. As shown in Fig. 2, addition of prolactin to the medium elevated the level of leptin secreted by the fat explants. Mammary fat explants secreted $2 \mathrm{ng} / \mathrm{ml}$ leptin to the medium with explants cultured with $0 \cdot 01 \mu \mathrm{g} / \mathrm{ml}$ prolactin, $6 \mathrm{ng} / \mathrm{ml}$ at $0.1 \mu \mathrm{g} / \mathrm{ml}$ prolactin, and $16 \mathrm{ng} / \mathrm{ml}$ at $1 \mu \mathrm{g} / \mathrm{ml}$ prolactin. At $10 \mu \mathrm{g} / \mathrm{ml}$ prolactin in the medium, leptin secretion was down-regulated to $12 \mathrm{ng} / \mathrm{ml}$.

Effects of leptin, prolactin, and leptin antagonist on $\alpha$-casein expression in explants from mammary glands of lactating cows

Mammary gland explants from lactating cows were incubated for 4 days in a medium with or without prolactin (at $1 \mu \mathrm{g} / \mathrm{ml}$ ), with or without leptin (at $50 \mathrm{ng} / \mathrm{ml}$ ), and with four different

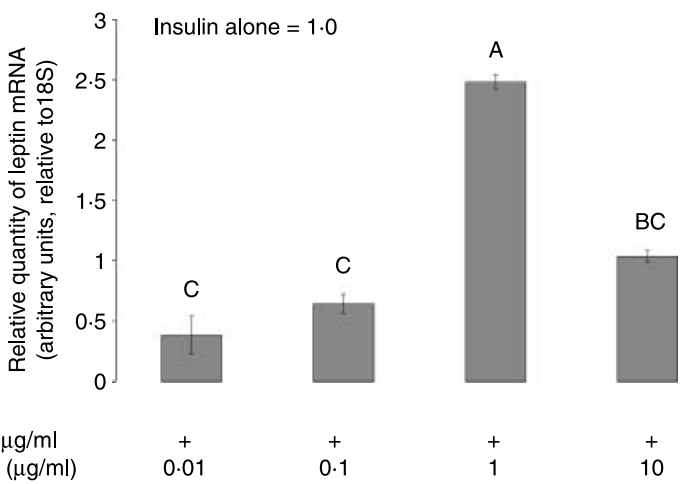

Figure 1 Expression of leptin mRNA in mammary gland explants from a lactating cow. The expression of leptin mRNA was determined by real-time PCR in mammary gland explants from a lactating cow. Leptin mRNA expression was determined after incubation with medium containing four different concentrations of prolactin $(0 \cdot 01-10 \mu \mathrm{g} / \mathrm{ml})$. The highest level of leptin mRNA expression was observed at the prolactin concentration of $1 \mu \mathrm{g} / \mathrm{ml}$. At $10 \mu \mathrm{g} / \mathrm{ml}$, leptin expression was down-regulated. Least square means \pm S.E.M. $(n=3)$. Bars with different letters differ $(P<0 \cdot 05)$. 


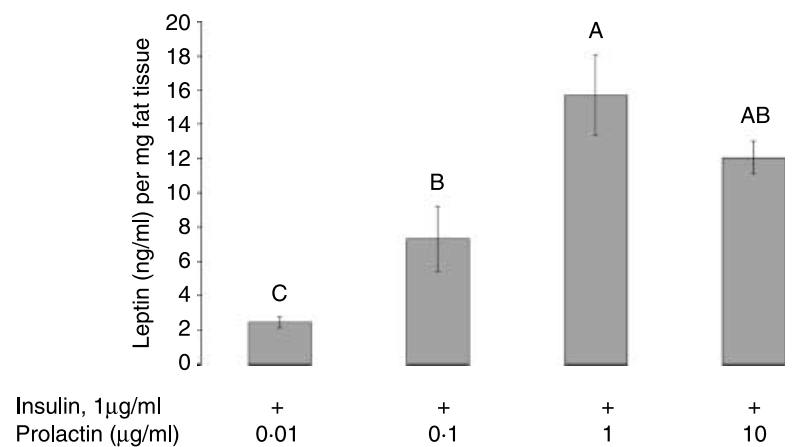

Figure 2 Secretion of leptin from bovine mammary gland fat explants. Mammary fat explants from a lactating cow were incubated in a medium containing four different levels of prolactin $(0 \cdot 01-10 \mu \mathrm{g} / \mathrm{ml})$. The highest level of leptin secretion $(16 \mathrm{ng} / \mathrm{ml})$ was observed at the prolactin concentration of $1 \mu \mathrm{g} / \mathrm{ml}$. At $10 \mu \mathrm{g} / \mathrm{ml}$ prolactin, leptin expression was down-regulated to $12 \mathrm{ng} / \mathrm{ml}$. Least square means \pm S.E.M. $(n=5)$. Bars with different letters differ $(P<0 \cdot 05)$.

levels of leptin antagonist (100-3200 ng/ml). Expression of the $\alpha$-casein gene was elevated $1 \cdot 8$-fold by prolactin; addition of leptin to medium containing prolactin augmented the base expression $2 \cdot 2$-fold. Leptin alone had no effect on $\alpha$-casein's expression in mammary gland explants cultured in a medium without prolactin. The addition of leptin antagonist to medium containing leptin and prolactin down-regulated $\alpha$-casein mRNA expression in a dose-dependent manner. The strongest inhibitory effect was observed at the antagonist concentration of $3200 \mathrm{ng} / \mathrm{ml}$. The lowest concentration of leptin antagonist $(100 \mathrm{ng} / \mathrm{ml})$ had no effect on $\boldsymbol{\alpha}$-casein mRNA expression (Fig. 3a). The addition of leptin antagonist to medium with no leptin abolished prolactin's effect on the expression of $\boldsymbol{\alpha}$-casein mRNA (Fig. 3b). This result strengthens the notion that leptin antagonist acts on exogenous as well as endogenous leptin.

\section{Effect of prolactin on $\alpha$-casein expression in primary cell culture from mammary glands of lactating cows with or without fat explant}

Primary cell culture from mammary glands of a lactating cow were incubated for 2 days in a medium containing three different levels of prolactin $(0 \cdot 01,0 \cdot 1$, or $1 \mu \mathrm{g} / \mathrm{ml})$ and $3200 \mathrm{ng} / \mathrm{ml}$ leptin antagonist. The primary culture was incubated with or without mammary fat explants. The expression of $\alpha$-casein in bovine mammary gland primary culture is shown in Fig. 4. The addition of prolactin to the medium elevated the level of $\boldsymbol{\alpha}$-casein mRNA expression in mammary cells incubated with mammary fat explant. The highest level of $\boldsymbol{\alpha}$-casein mRNA expression in the mammary cells was observed at the prolactin concentration of $1 \mu \mathrm{g} / \mathrm{ml}$. Leptin antagonist abolished the enhancement of $\boldsymbol{\alpha}$-casein expression. The expression of $\boldsymbol{\alpha}$-casein in primary culture that was not incubated with fat explant did not change dramatically, except at the level of $1 \mu \mathrm{g} / \mathrm{ml}$ prolactin. Throughout the experiment, $\boldsymbol{\alpha}$-casein expression was robust in the treatments containing fat explants relative to the primary culture alone.

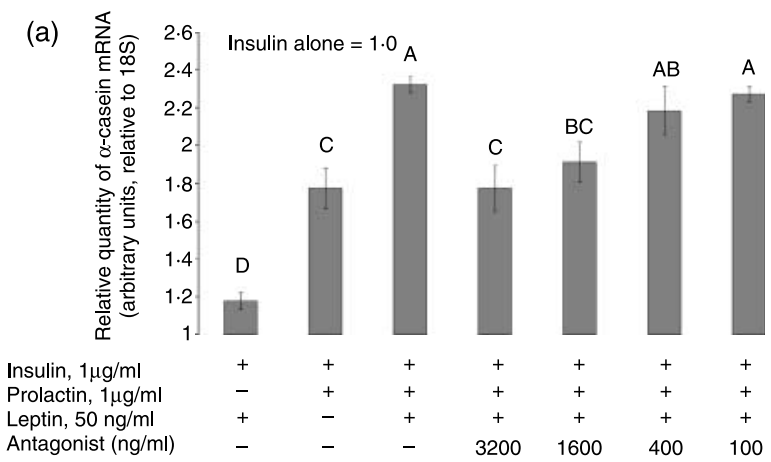

(b)

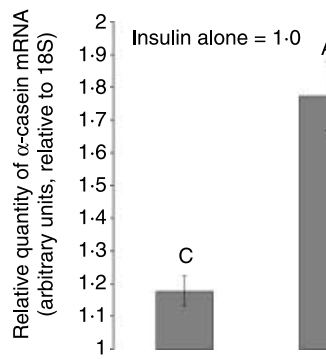

Insulin, $1 \mu \mathrm{g} / \mathrm{ml}$

Prolactin, $1 \mu \mathrm{g} / \mathrm{ml}$

Leptin, $50 \mathrm{ng} / \mathrm{ml}$

Antagonist (ng/ml)

+
-
+

$+$
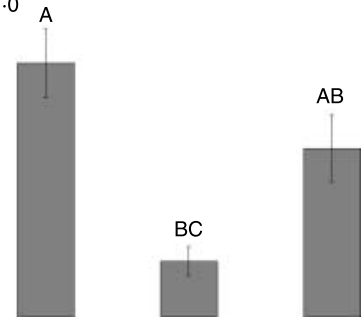

Figure 3 Inhibition of $\alpha$-casein gene expression in primary cultures of bovine mammary gland explants by leptin antagonist

(L39A/D40A/F41A). (a) Mammary gland explants from a lactating cow were incubated in a medium with or without prolactin (at $1 \mu \mathrm{g} / \mathrm{ml}$ ), with or without leptin (at $50 \mathrm{ng} / \mathrm{ml}$ ), and with four different concentrations of leptin antagonist (100-3200 ng/ml). $\alpha$-Casein gene expression was elevated (80\% compared with insulin treatment) by prolactin; addition of leptin to the medium containing prolactin augmented the expression of $\alpha$-casein by $120 \%$ (relative to the insulin treatment). Leptin alone had no significant effect on $\alpha$-casein expression in a medium without prolactin. The addition of leptin antagonist to medium containing leptin and prolactin down-regulated $\alpha$-casein mRNA expression in a dose-dependent manner, with the strongest effect at $3200 \mathrm{ng} / \mathrm{ml}$ antagonists. A low concentration of leptin antagonist $(100 \mathrm{ng} / \mathrm{ml})$ had no effect on $\alpha$-casein mRNA expression. (b) Leptin antagonist abolished prolactin's effect on the expression of $\alpha$-casein mRNA in explants that were incubated only with insulin $(1 \mu \mathrm{g} / \mathrm{ml})$ and prolactin $(1 \mu \mathrm{g} / \mathrm{ml})$. Least square means \pm s.E.M. $(n=3)$. Bars with different letters differ $(P<0 \cdot 05)$.

Expression of tissue-specific markers for mammary primary cell culture, mammary explants, and fat explants

The expression of Adipo-Q and $\boldsymbol{\alpha}$-casein was examined by RT-PCR in bovine mammary explants, primary culture, and mammary fat pad. The expression of Adipo-Q was observed in the mammary fat and mammary explant. No Adipo-Q was detected in the mammary primary cell culture. $\alpha$-Casein expression was detected in the mammary explants and the mammary primary culture. No $\alpha$-casein was detected in the fat explants (Fig. 5). 


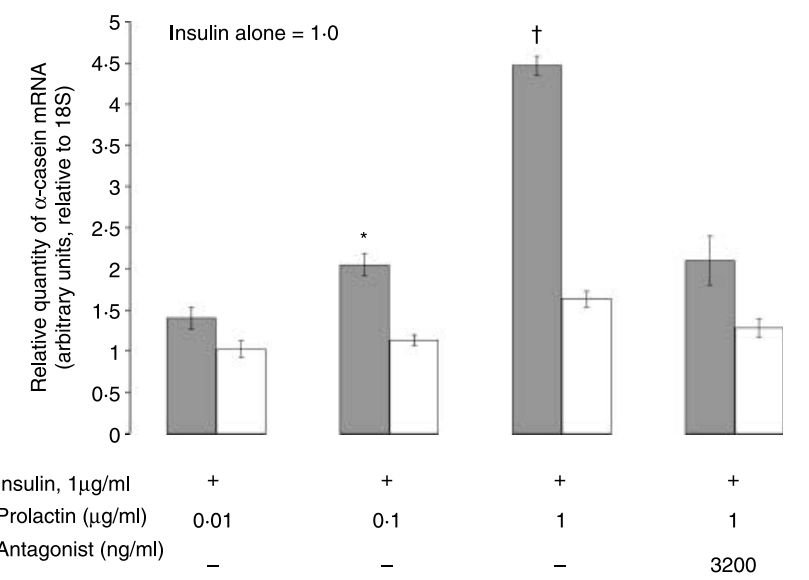

Figure 4 The effect of fat explant on $\alpha$-casein expression in bovine mammary gland primary cell culture. The expression of $\alpha$-casein was examined in primary culture that was incubated with mammary fat explant (closed bars) or without mammary fat explant (open bars). Four treatments were introduced: three different levels of prolactin $(0 \cdot 01,0 \cdot 1$, and $1 \mu \mathrm{g} / \mathrm{ml})$ and one combined treatment of leptin antagonist $(3200 \mathrm{ng} / \mathrm{ml})$ and $1 \mu \mathrm{g} / \mathrm{ml}$ prolactin. The expression of $\alpha$-casein in primary culture incubated with no fat explants did not change significantly with any treatment. A significant difference in the expression of $\alpha$-casein between the treatments containing fat explants and those without was observed at prolactin concentrations of 0.1 and $1 \mu \mathrm{g} / \mathrm{ml}$ prolactin. Leptin antagonist abolished the differences between the two treatments (with fat and without). Results are least square means \pm S.E.M. of four independent experiments $(n=4) .{ }^{*+}$ Means differing at $P<0.05$ and $P<0.001$ respectively between treatments with and without fat explant.

\section{Discussion}

In mouse and ovine mammary tissues, leptin gene expression changes throughout pregnancy and lactation (Aoki et al. 1999, Bonnet et al. 2002). One of the factors involved in the transition to lactation is prolactin (Neville et al. 2001). We believe that prolactin is the key factor signaling the mammary gland to interact with leptin in the regulation of milk synthesis during lactation. In this work, we give an additional piece of evidence that prolactin can alter leptin secretion and expression in the bovine mammary fat, and leptin expression in the bovine mammary gland of the lactating cows (Figs 1 and 2). These results stand together with other studies which have demonstrated that prolactin elevates leptin mRNA in rat adipose tissue (Gualillo et al. 1999). Brogan et al. (1999) reported that during lactation, when the level of prolactin is high, the level of serum leptin is low, results which may be considered contradictory to ours. However, the discrepancy in the data may be explained as follows: we claim that the low level of serum leptin at the beginning of lactation, when prolactin level is high, represents the whole peripheral system, which has to deal with the new metabolic status brought about by lactation, while our results demonstrate the local effect of prolactin on leptin's action in the bovine mammary gland. This notion is supported by Silva et al. (2002), who show that the bovine

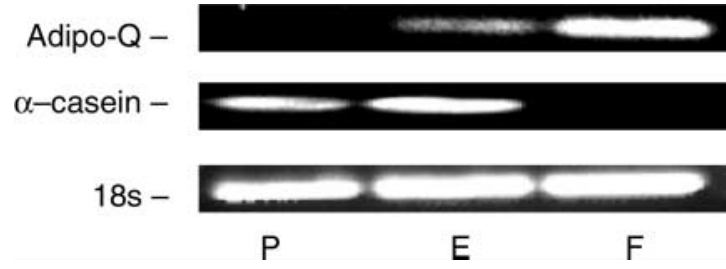

Figure 5 Expression of tissue-specific markers for mammary primary cell culture, mammary explants, and fat explants. The expression of Adipo-Q, $\alpha$-casein, and 18s mRNA was analyzed in bovine mammary explants $(E)$, primary culture $(P)$, and mammary fat $(F)$. Adipo-Q was detected in the mammary fat pad and mammary explants. Adipo-Q was not detected in the mammary primary cell culture. $\alpha$-Casein expression was detected only at mammary explants and mammary primary culture.

mammary gland expresses the long form of the leptin receptor $(\mathrm{OB}-\mathrm{Rb})$, and claim that the local concentration of leptin in the prepubertal mammary gland might not be reflected in the leptin concentration in the serum. Additional support for our claim can be found in the study by Accorsi et al. (2005), which examined the plasma level of several hormones in dairy cows, including prolactin and leptin during lactation. This group found that the concentration of the leptin plasma levels has significantly increased from the fourth to the sixth month of lactation, surprisingly the level of prolactin increased at the parallel period.

To understand the interaction between prolactin and leptin in the bovine mammary gland, we examined their combined effect on the mammary gland with or without leptin antagonist. In the presence of prolactin, leptin enhanced expression of the $\alpha$-casein gene; this finding confirms our previous work which demonstrated that leptin and prolactin interact to alter milk synthesis in the bovine mammary gland (Feuermann et al. 2004). In the present study, we examined the effect of leptin antagonist on the expression of $\alpha$-casein gene in the presence of prolactin and leptin. Leptin antagonist abolished leptin effect on prolactin action in the mammary gland explants. When leptin antagonist was added to the explants medium containing only prolactin, it inhibited expression of the $\alpha$-casein gene in the mammary explants. However, when leptin was not present in the medium, the inhibitory effect followed a pattern similar to that in the experiment containing leptin, but was of a lower magnitude. The ability of leptin antagonist to abolish leptin influence in tissues and cells was well established in Niv-Spector et al. (2005) work. Our explanation for these results lies in the unique system utilized. Our study was performed with mammary gland explants and not a cell line. The explants contain almost all of the cells in the secretory unit of the mammary gland, including adipocytes (see Fig. 5). We believe that the addition of prolactin to the medium, initiated leptin secretion from the adipocyte within the mammary gland explants, a finding that is supported by Gualillo et al. (1999), who found that prolactin elevated leptin mRNA in rat adipose tissue. Additional support for this hypothesis can be 
found in Fig. 1, and in our previous study which demonstrated that leptin mRNA expression is up-regulated in lactating cow when compared with the heifer's mammary gland (Feuermann et al. 2004). The involvement of adipocytes in the mammary gland has not been completely established, although during the past there were different studies which showed that adipocytes and mammary fat are present during lactation. For example, Howe et al. (1975) established the fact that adipocytes are found in the bovine lactating mammary gland. In the 1970s, Komatsu et al. (2003) had demonstrated the expression of resistin in adipose tissue and mammary gland of lactating and non-lactating cows. Resistin was identified as an adipocytes-secreted factor (Steppan et al. 2001) and Komatsu's group had shown that resistin is expressed in the mammary gland during lactation, although the expression of resistin was higher in non-lactating cow when compared with lactating cows. It is important to emphasize that the level of resistin expression in preadipocytes is higher compared with mature adipocytes (Janke et al. 2002), but still resistin as an adipocyte-secreted factor is expressed in peak lactating mammary gland.

In order to investigate whether the mammary autocrine secretion of leptin is involved in the regulation of prolactin effect on lactation, we performed a series of co-culture experiments with primary culture of mammary cells and mammary fat explants (which were obtained from the hind side of the udder). We examined the expression of the $\alpha$-casein gene in the primary culture of mammary epithelial cells with or without mammary fat explants (Fig. 4). These experiments revealed that although epithelial cells in culture express $\boldsymbol{\alpha}$-casein after stimulation by prolactin (up regulation of $\sim 50 \%$ at $1 \mu \mathrm{g} / \mathrm{ml}$ ), in the presence of fat explants, the epithelial cells reach their full gene-expression potential of $\alpha$-casein. Addition of leptin antagonist diminished the effect of the fat explants on $\boldsymbol{\alpha}$-casein gene expression in the primary culture, a finding that clearly points to the role of leptin secreted from mammary fat in the regulation of milk synthesis in the bovine mammary gland. These findings are supported by the findings of Hovey et al. (1998), who reported a stimulatory effect of mouse fat pad when co-cultured with a mouse mammary epithelial cell line (COMMA-1D). The co-culture experiments emphasized the role of the mammary gland adipocytes/fat pad in the regulation of lactation. The purpose of this work was to study the interaction and importance of leptin originated from fat in the regulation of lactogenesis. Using leptin antagonist allows us to isolate the effect of leptin on the mammary cells. Moreover, one can see that there are more factors in the adipose tissue that interact with mammary cells. The results presented in Fig. 4 clearly show that leptin antagonist cannot completely abolish the effect of the fat explants on the mammary cells.

Taken together, these findings strongly support our hypothesis that leptin, which is secreted from the mammary fat deposits, interacts with the mammary epithelial cells after prolactin stimulation.

\section{Acknowledgements}

We thank Prof. A Gertler for the gift of bovine recombinant leptin and for prompting us to employ leptin antagonist. We are also grateful for support from the Cattle Breeders' Association of Israel. The authors declare that there is no conflict of interest that would prejudice the impartiality of this scientific work.

\section{References}

Accorsi PA, Govoni N, Gaiani R, Pezzi C, Seren E \& Tamanini C 2005 Leptin, GH, PRL, insulin and metabolic parameters throughout the dry period and lactation in dairy cows. Reproduction in Domestic Animals 40 217-223.

Aoki N, Kawamura M \& Matsuda T 1999 Lactation-dependent down regulation of leptin production in mouse mammary gland. Biochimica et Biophysica Acta 1427 298-306.

Bonnet M, Gourdou I, Leroux C, Chilliard Y \& Djiane J 2002 Leptin expression in the ovine mammary gland: putative sequential involvement of adipose, epithelial, and myoepithelial cells during pregnancy and lactation. Journal of Animal Science 80 723-728.

Brogan RS, Mitchell SE, Trayhurn P \& Smith MS 1999 Suppression of leptin during lactation: contribution of the suckling stimulus versus milk production. Endocrinology 140 2621-2627.

Chomczynski P \& Sacchi N 1987 Single-step method of RNA isolation by acid guanidinium thiocyanate-phenol-chloroform extraction. Analytical Biochemistry 162 156-159.

Conn MP \& Melmed S Eds 1997 Endocrinology: Basic and Clinical Principles. Totowa, New Jersey: Humana Press.

Feuermann Y, Mabjeesh SJ \& Shamay A 2004 Leptin affects prolactin action on milk protein and fat synthesis in the bovine mammary gland. Journal of Dairy Science 87 2941-2946.

Friedman JM \& Halaas JL 1998 Leptin and the regulation of body weight in mammals. Nature 395 763-770.

Fruhbeck G 2001 A heliocentric view of leptin. Proceedings of the Nutrition Society 60 301-318.

Groner B 2002 Transcription factor regulation in mammary epithelial cells. Domestic Animal Endocrinology 23 25-32.

Gualillo O, Lago F, Garcia M, Menendez C, Senaris R, Casanueva FF \& Dieguez C 1999 Prolactin stimulates leptin secretion by rat white adipose tissue. Endocrinology 140 5149-5153.

Hovey RC, MacKenzie DD \& McFadden TB 1998 The proliferation of mouse mammary epithelial cells in response to specific mitogens is modulated by the mammary fat pad in vitro. In Vitro Cellular and Developmental Biology-Animal 34 385-392.

Hovey RC, McFadden TB \& Akers RM 1999 Regulation of mammary gland growth and morphogenesis by the mammary fat pad: a species comparison. Journal of Mammary Gland Biology and Neoplasia 4 53-68.

Howe JE, Heald CW \& Bibb TL 1975 Histology of induced bovine lactogenesis. Journal of Dairy Science 58 853-860.

Janke J, Engeli S, Gorzelniak K, Luft FC \& Sharma AM 2002 Resistin gene expression in human adipocytes is not related to insulin resistance. Obesity Research 10 1-5.

Komatsu T, Itoh F, Mikawa S \& Hodate K 2003 Gene expression of resistin in adipose tissue and mammary gland of lactating and non-lactating cows. Journal of Endocrinology 178 R1-R5.

Moschos S, Chan JL \& Mantzoros CS 2002 Leptin and reproduction: a review. Fertility and Sterility 77 433-444.

Neville MC, Morton J \& Umemura S 2001 Lactogenesis. The transition from pregnancy to lactation. Pediatric Clinics of North America 48 35-52.

Niv-Spector L, Gonen-Berger D, Gourdou I, Biener E, Gussakovsky EE, Benomar Y, Ramanujan KV, Taouis M, Herman B, Callebaut I et al. 2005 
Identification of the hydrophobic strand in the A-B loop of leptin as major binding site III: implications for large-scale preparation of potent recombinant human and ovine leptin antagonists. Biochemical Journal 391 221-230.

SAS 2001 SAS User's Guide: Statistic Release 8·2. SAS Inst., Inc., Cary, NC.

Shamay A, Zeelon E, Ghez Z, Cohen N, Mackinlay AG \& Gertler A 1987 Inhibition of casein and fat synthesis and alpha-lactalbumin secretion by progesterone in explants from bovine lactating mammary glands. Journal of Endocrinology 113 81-88.

Silva LF, VandeHaar MJ, Weber Nielsen MS \& Smith GW 2002 Evidence for a local effect of leptin in bovine mammary gland. Journal of Dairy Science $\mathbf{8 5}$ 3277-3286.
Steppan CM, Bailey ST, Bhat S, Brown EJ, Banerjee RR, Wright CM, Patel HR, Ahima RS \& Lazar MA 2001 The hormone resistin links obesity to diabetes. Nature 409 307-312.

Zangani D, Darcy KM, Shoemaker S \& Ip MM 1999 Adipocyte-epithelial interactions regulate the in vitro development of normal mammary epithelial cells. Experimental Cell Research 247 399-409.

Received in final form 7 August 2006 Accepted 8 August 2006 